\title{
Wisdom of indigenous and tacit knowledge for disaster risk reduction
}

\author{
Furqan Ishak Aksa \\ Department of Geography Education, Samudra University, Langsa, Indonesia
}

Received: 2019-10-19

Accapted: 2020-11-12

Keywords:

Tacit Knowledge;

Indigenous;

Disaster;

Hazard;

Risk Reduction

Correspondent email:

furqanishaksa@unsam.ac.id

\begin{abstract}
This article aims to identify the types of knowledge needed in reducing the risk of disasters and challenges in applying knowledge. Based on the literature review, this article analyzes various kinds of knowledge, the process of knowledge creation, and the challenges of knowledge transmission. Basically, knowledge consists of explicit and tacit knowledge. In the context of disasters, most of the knowledge is tacit in individual local people (indigenous knowledge). Tacit knowledge can motivate someone to make decisions (act) when a disaster occurs. To be understood and disseminated to the wider community, tacit knowledge needs to be converted into explicit knowledge and scientifically validated. This article proposes the importance of integrating tacit knowledge in the form of local knowledge to become explicit knowledge so it can be widely used. Knowledge built in a bottom up manner, which comes from local knowledge, is believed to be effective in disaster risk reduction. However, in some countries, the process of applying knowledge is constrained by fatalism that is influenced by social culture and religious beliefs.
\end{abstract}

2020 by the authors. Licensee Indonesian Journal of Geography, Indonesia.

This article is an open access article distributed under the terms and conditions of the Creative Common

Attribution(CC BY NC) licensehttps://creativecommons.org/licenses/by-nc/4.0/.

\section{Introduction}

Knowledge is an essential aspect in efforts to reduce disaster risk (Pathirage, Seneviratne, Amaratunga, \& Haigh, 2012; Weichselgartner \& Pigeon, 2015). The knowledge of each individual strongly influences decision making when a disaster occurs. The 2004 Indian Ocean earthquake and tsunami has proven that the tsunami's lack of knowledge has caused approximately 165,791 Acehnese to die (BNPB, 2019). Many victims are caused by errors in decision making when a disaster occurs (Iemura, Takahashi, Pradono, Sukamdo, \& Kurniawan, 2006; McAdoo, Dengler, Prasetya, \& Titov, 2006). After an earthquake with a strength of 9 SR, the community packed the shoreline to collect fish as the sea water receded. The Acehnese did not have the knowledge that low tide was a sign of a tsunami. The same thing happened when an earthquake and tsunami struck Samoa in 2009, many victims died in their cars because they chose to evacuate by car, even though there were hills that could be used as evacuation sites.

The tsunami disaster caused by the eruption of Anak Krakatau volcano that hit the Sunda Strait, Indonesia in December 2018 also revealed that knowledge of tsunami disaster was still very lacking. Most people assume that tsunamis are only caused by earthquakes. The people who were on Tanjung Lesung beach were surprised by the tsunami because they did not feel an earthquake before the tsunami hit the coast of Tanjung Lesung. Even though tsunamis are not only caused by earthquakes, volcanic activities can also cause tsunami (Mardiatno, Malawani, Annisa, \& Wacano, 2017). Besides, there was no information on the threat of a tsunami disaster issued by relevant agencies. New tsunami warnings were issued by the Meteorology and Geophysics Agency (BMKG) shortly after the tsunami hit land. The lack of knowledge and information about the tsunami disaster threat caused 437 people to die, 31,943 injured, and 10 people missing (BNPB, 2019). Most of the victims were tourists who were on year-end holidays at Tanjung Lesung beach.

Previous studies also revealed that knowledge about disasters was still very lacking. Findings from a study conducted by Kanhai et al., (2016) in coastal communities in Trinidad and Tobago, Caribbean State found that most people did not have tsunami awareness (only 20\% had basic knowledge of the tsunami disaster, $57 \%$ knew natural signs in their environment that can be used to predict tsunami disasters, and $92 \%$ are unaware of past tsunamis in the Caribbean). Another study on disaster knowledge was carried out by Bosschaart et al., (2013). By surveying 483 students aged 15 years from various flood-prone areas in the Netherlands, the study found that the level of student knowledge about flooding was very limited.

Some examples of cases presented above are only a small portion of the portrait of the community's limited knowledge about disasters in various worlds. The lack of knowledge about disasters is very worrying as disaster events tend to increase every year. Therefore, stakeholders are increasingly aware that people need to be equipped with a knowledge to increase their capacity to face disasters. The Third United Nation World Conference proved this results held in Sendai 
on March 18, 2015 which produced the 2015-2030 The Sendai Framework for Disaster Risk Reduction (SFDRR). The conceptual framework emphasized the importance of knowledge for disaster risk reduction in the future. It is stated in paragraph 19 that multi-hazard approach and inclusive risk-informed decision-making based on risk reduction requires a broad exchange and dissemination of disaggregated data, including sex, age and disability, as well as on the easily accessible, up-to-date, comprehensible, science-based, non-sensitive risk information, complemented by traditional knowledge (UNISDR, 2015).

However, there is still very limited literature that specifically addresses kind of knowledge needed by the community in dealing with disasters. Many people know about disasters, but they do not know the actions that can be taken to reduce disaster risk. Songlar, Pussadee La-or, Chomchoe, \& Khunthason (2019) found that even though most of the people of Chiang Rai, Thailand have good knowledge of the causes and impacts of an earthquake, most of them have a wrong understanding of the actions that must be taken when it occurs, for example they state that people must return to the building immediately after an earthquake. The action was not justified because generally after an earthquake there are often aftershocks that can damage the building and endanger them in it (Songlar et al., 2019).

This article aims to identify the types of knowledge needed to increase community capacity in the face of disasters. By examining various literature, the discussion in this paper begins by explaining comprehensively the dimensions of knowledge, the process of knowledge creation, the challenges in knowledge integration and the final section will discuss the challenges of applying knowledge.

\section{The Methods}

This article uses secondary data as the main source. Data were collected from previous studies related to disaster knowledge and knowledge management. The search process for this review utilized several databases including Web of Science, Taylor \& Francis, Google Scholar, Science Direct, and Elsevier. The titles and abstracts of articles were searched for the keywords" knowledge management"," indigenous knowledge"," explicit knowledge", and" disaster knowledge". Specifically, the scanned article is focused on journals that study disasters such as Disaster, Disaster Risk Reduction, Disaster Risk Science, Natural Hazard, Geomatics, Natural
Hazard and Risk, dan others journals dedicated to disaster studies. After thoroughly scanned, there were finally 37 relevant articles to be analyzed. The time span of the article was found from 1995 to 2020 (see table 1 in the appendix).

\section{Result and Discussion}

\section{Dimensions of Knowledge}

Knowledge consists of explicit and tacit knowledge (Gao, Meng, \& Clarke, 2008; North \& Kumta, 2014). Explicit knowledge is a type of knowledge that can be easily processed by a computer, transmitted to other people in formal and electronic languages, or stored in a database. Personal tacit knowledge is embedded in individual experience and involves intangible factors such as personal beliefs, insights, perspectives, and value systems (Murumba, 2020). Tacit knowledge is difficult to encode, formalized and articulated in formal languages (Ajith Kumar \& Chakrabarti, 2012; Boiral, 2002; Fazey, Proust, Newell, Johnson, \& Fazey, 2006; Raymond et al., 2010). In order to be transmitted, tacit knowledge must be changed in the form of words, models, or numbers so that they can be understood. Knowledge is only a small amount that is explicit. Most knowledge is stored in individuals (North \& Kumta, 2014).

Dalkir, K. (2013) makes a comparison of properties of tacit vs explicit knowledge (table 1). Compared to explicit knowledge, tacit knowledge has a wealth of "ability to adapt, to deal with new and exceptional situations, expertise, and know-how. In addition, knowledge transfer is carried out based on personal experience done in person. In the context of disaster, the knowledge needed to save oneself in the event of a disaster is tacit knowledge (Raymond et al., 2010). Tacit knowledge can motivate someone to make decisions (act) when a disaster occurs. Most tacit knowledge is embedded in local communities in the form of indigenous knowledge. After the devastating Indian Ocean earthquake and tsunami in 2004, disaster scientists and practitioners realized that indigenous knowledge made a major contribution in saving lives during disasters (Becker, Johnston, Lazrus, Crawford, \& Nelson, 2008; Hiwasaki, Luna, Syamsidik, \& Shaw, 2014; J. Mercer, Kelman, \& Dekens, 2009). One of them is the local knowledge of Smong practiced by the Simeulue people, Aceh, which has saved many lives.

Findings of the study conducted by Rahman et al (2018) explain that the development of Smong Story which was started since 1907 has formed the tacit knowledge of the Simeulue community. Learning from the history of the

Table 1. Comparison of properties of tacit and explicit knowledge.

Ability to adapt, to deal with new and exceptional situations.

Expertise, know-how, know-why, and care-why.

Ability to collaborate, to share a vision, to transmit a culture.

Coaching and mentoring to transfer experiential knowledge on a one-to-one, face-to-face basis
Ability to disseminate, to reproduce, to access, and to reapply throughout the organization.

Ability to teach, to train

Ability to organize, to systematize; to translate a vision into a mission statement, into operational guidelines

Transfer of knowledge via products, service, and documented processes 
earthquake and tsunami that struck Simeulue in 1907 has encouraged the Simeulue community to pass this knowledge on to the next generations. This is done in the form of folklore and poems read for their children before they go to sleep. The stories and poems contain messages about tsunami disasters and efforts to save lives when the disaster returns. These stories have been embedded in the subconsciousness of the Simeulue community so as to form tacit knowledge (Rahman, Sakurai, \& Munadi, 2018; Syahputra, 2018). This greatly helped decision making when the earthquake and tsunami struck Aceh in December 2004. At that time, only 7 people were killed in Simeulue. This is because the Simeulue people took the right course of action by moving away from the shoreline after the earthquake. This condition is inversely proportional to the people in Banda Aceh City. When the earthquake occurred in December 2004, many people in Banda Aceh did not move away from the shoreline. This is due to ignorance among community members about the tsunami disaster.

The same thing was practiced by local people in Vanuatu Islands and Solomon Islands. Local knowledge of the village community about tsunami risk played an important role in helping them survive the tsunami disaster occurring in the Vanuta Islands in 1999 and the tsunami in the Solomon Islands in 2007 (Lauer, 2012). The tsunami that occurred in the Solomon Islands in 2007 was triggered by an earthquake with a magnitude of 8.1 SR. The disaster killed 52 people (McAdoo, Moore, \& Baumwoll, 2009). Most victims were immigrants who did not have local knowledge (McAdoo et al., 2009). Many local residents survived owing to their right response when the tsunami struck. The death toll might have been higher if local people had not run to the hills behind their villages to save themselves.

Another example of the formation of tacit knowledge was practiced by the people of Takamatsu City. The transfer of knowledge between generations about the history of large storms (Isewan Typhoon and Second Muroto Typhoon) that hit the city of Takamatsu in 1959 and 1961 was then carried out continuously from one generation to the next. It aims at Lesson Learned (learning from the past), so that future generations understand the history of disasters in their region and can make the right decisions when a disaster occurs in the future. An understanding of the history of disasters makes people aware that they live in disaster sites (Nakanishi \& Black, 2018).

Local knowledge practiced by the people of Simeulue, Vanuatu Islands, Solomon Islands, and Takamatsu is only a small part of the type of tacit knowledge that is spread in individuals and local communities in various worlds. Nevertheless, tacit knowledge in the form of local knowledge needs to be converted into explicit knowledge and validated with science so that it can be used and disseminated to the wider community. Local knowledge (tacit) will be very effective for use in the face of disasters when combined and scientifically validated (McAdoo et al., 2009).

\section{Knowledge conversion}

To be understood and disseminated to the wider community, tacit knowledge needs to be converted into explicit knowledge. There are several knowledge conversion models that have been developed by experts, for example SECI-Model developed by (Nonaka \& Takeuchi, 1995). The model introduces four ways to convert knowledge, namely the process of socialization (tacit to tacit), externalization (tacit to explicit), combination (explicit to explicit), and internalization (explicit to tacit) (See Figure 1). Socialization is the conversion of someone's tacit knowledge to other people's tacit knowledge. Socialization is a process of sharing knowledge directly (naturally) that can be done by way of observation, imitation, and direct practice (North \& Kumta, 2014).

Externalization is the process of articulating tacit knowledge into explicit knowledge. Combination is the process of reconfiguring existing information by sorting, adding, merging, or combining so as to produce new knowledge (Dalkir, 2013; North \& Kumta, 2014). The final

\section{THE NONAKA AND TAKEUCHI KNOWLEDGE SPIRAL}

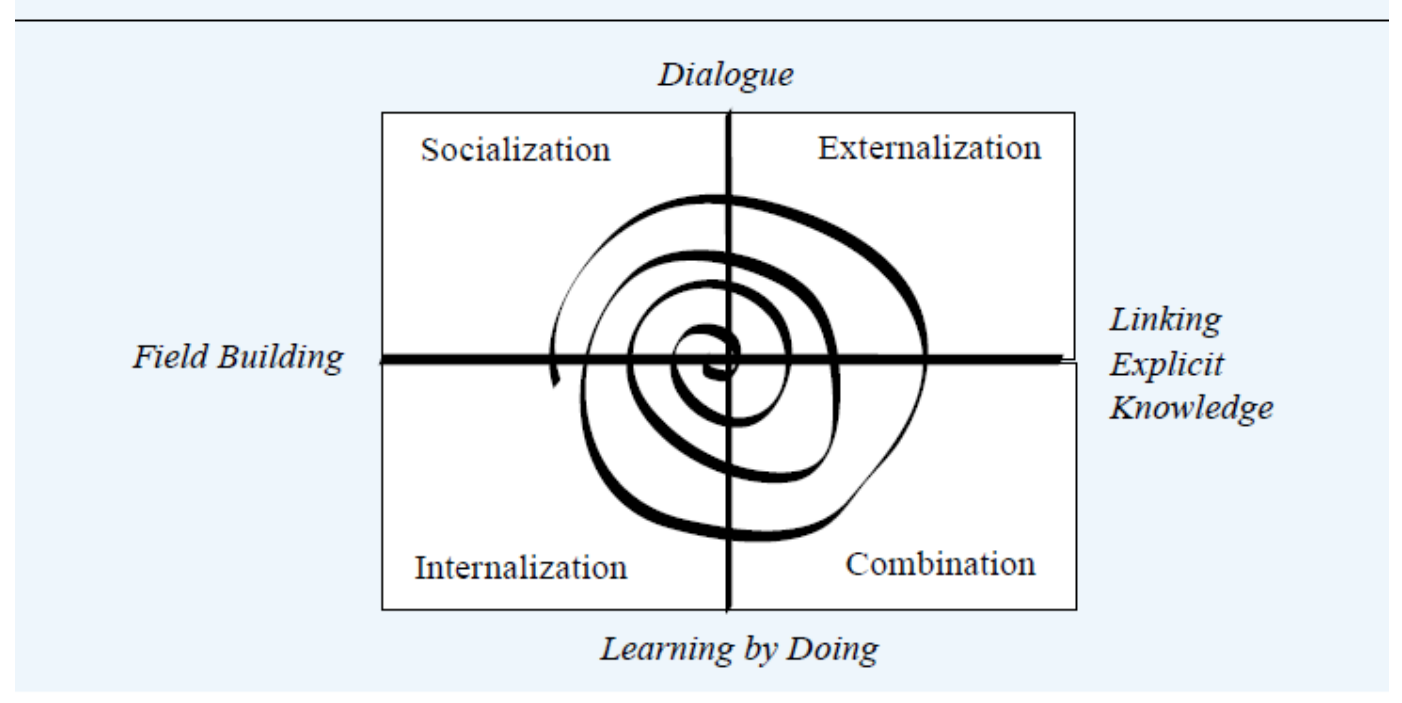

Figure 1. Knowledge Spiral Model

Source: Adapted from Nonaka and Takeuchi (1995) 
process of conversion of knowledge is Internalization, which is to instill new acquired knowledge. This is related to "Learning by doing". An important aspect of knowledge conversion is the continuous and dynamic interaction between tacit knowledge and explicit knowledge at personal and group level (Nonaka \& Takeuchi, 1995).

One example of the process of integrating local knowledge (tacit) into explicit knowledge has been carried out by the Washington State Emergency Management Division. The activity was based on the high risk of earthquake and tsunami in Washington State. Geologically, the area is located in the Cascadia Subduction Zone (CSZ) which is prone to earthquakes. CSZ is considered capable of producing earthquakes reaching 9 SR (Becker et al., 2008). An earthquake with a large power is expected to cause a tsunami with a height of up to 10 meters. The history of past disasters in Washington State is known through Native American folk traditions in the form of stories, art and ceremonies (Becker et al., 2008). To reduce the number of victims in the future, local knowledge about earthquake and tsunami disaster was made in the form of a video titled "Run to Higher Ground!'. The video contains stories from Native Americans about earthquake and tsunami disasters. The story is based on the disasters in the Pacific Northwest around 1700 .

When referring to the SECI Model, the knowledge conversion process carried out by the Washington State Emergency Management Division starts from the Socialization process (tacit to tacit knowledge). This is done by exploring/identifying the traditions of the American people by meeting with the main sources among tribes in America to help them understand the oral traditions of earthquake and tsunami. Tacit knowledge gained from the results of discussions with tribes is then Externalized (tacit to explicit). Then, Combination is done by sorting, merging, so as to produce new knowledge in the form of a video "Run to Higher Ground! '. The last process of Internalization is to instill new acquired knowledge. This is done by distributing this knowledge to various places, schools and other institutions in the United States and internationally (Becker et al., 2008).

The knowledge of tsunamis packaged in the form of a video "Run to Higher Ground!" is very useful when a disaster occurs. This was proven when an earthquake on June 14, 2005 with a magnitude of 7.2 off the coast of Northern California followed by a small tsunami (only a few centimeters). La Push is one of the communities in Washington that was affected. The response of the La Push community during the tsunami was very good. After hearing the siren issued by the local authority, within 15 minutes the evacuation process was successfully carried out. The only people who were not evacuated were a few tourists who were in tourist resorts. Tourists did not understand the meaning of tsunami warnings because they were not members the local community of La Push (Becker et al., 2008).

The process of integrating local knowledge with science has also been carried out by Hiwasaki et al (2014). The activity is a project developed by the United Nations Educational, Scientific and Cultural Organization (UNESCO) Jakarta Office. The process of integrating local knowledge with science is related to the hydrometeorological disaster in coastal communities and small islands in Indonesia, Philippines and Timor Leste. The stages of integrating local knowledge with science carried out in principle are almost the same as the SECI Model. The process begins with observation, documentation, validation, and categories. However, the process of integrating tacit knowledge in the form of local knowledge often faces challenges. One of them is the discovery of local community's trust that their traditional knowledge is considered sacred so that it cannot be disseminated to the wider community. Only key people in indigenous communities may possess this knowledge (Becker et al., 2008).

Some examples of integration from tacit knowledge to explicit knowledge or vice versa will not benefit disaster risk reduction efforts if not implemented. The SECI model developed by Nonaka and Takeuchi (1995) emphasizes on the Internalization aspect of instilling new acquired knowledge. This is related to "Learning by doing". Therefore, in the context of disaster risk reduction, the interaction between tacit knowledge becomes explicit and vice versa must be done routinely and continuously.

Success in the conversion of knowledge is when someone can act / make decisions appropriately. This level will be obtained if the knowledge that has been obtained is practiced/applied. It aims to increase motivation in acting / decision making when a disaster occurs. Disaster education is not only limited to the formation of knowledge of know what or explicit knowledge. However, it is necessary to apply directly in the field in the form of simulation / draft. This is very important for forming tacit knowledge. Knowledge gained from personal experience can help make the right decision when a disaster occurs (Spiekermann, Kienberger, Norton, Briones, \& Weichselgartner, 2015).

Learning from the experience of the massive earthquake that hit Japan on March 11, 2011, disaster education taught to students regularly for seven years was able to save 2,900 lives of students located in the coastal city of Kamaishi (Sakurai et al., 2018). The story is known as "The Miracle of Kamaishi". Of course this is not a miracle, but the result of a long process in school-based disaster risk reduction education. Schools located in coastal areas with a high risk of tsunami disaster routinely carry out tsunami evacuation drills. Disaster education taught to students presents examples of past disasters in their area (Sakurai et al., 2018).

\section{Challenges in applying knowledge}

Decision making when a disaster occurs is influenced by knowledge, socio-cultural factors, and trust in the norms embedded in the community (Wachinger, Renn, Begg, \& Kuhlicke, 2013). Therefore, knowledge of disasters that have been obtained both through direct experience and education cannot easily be applied in decision making when a disaster occurs. One of the obstacles in applying knowledge is fatalism which is influenced by social culture and religious beliefs.

Belief in fatalism is an attitude that considers that everything is caused by luck. The fatalism attitude was believed by most pre-industrial societies in medieval Europe and modern society in some countries with low economic conditions (Akasoy, 2007). In the context of disasters, fatalism attitudes affect the majority of the Muslim population in the world (Baytiyeh \& Naja, 2014). This is corroborated by several findings from previous studies, for example, a study conducted by Paradise (2005) which 
assessed the perception of the Marocco Muslim community on earthquake disasters revealed that respondents who were low educated generally tended to link earthquake disasters as divine will (Allah SWT ) Questions about the possible frequency of future earthquakes, the respondent answered "Allahu a'lam" or "God is wisest". It can be interpreted that every effort to predict earthquake risk, earthquake-safe building construction is "unclean" or prohibited in Islam (Paradise, 2005). Furthermore, the study revealed that respondents who were low educated assumed that Allah protected the pious people who were obedient to Allah SWT (Paradise, 2005).

The same thing happened to the people of Saudi Arabia. The study conducted by Alshehri et al (2013) in 13 regions of Saudi Arabia revealed that the majority of respondents thought that various types of disasters that hit Saudi Arabia were punishments from Allah SWT. The majority of Saudi Arabia people have faith (belief) that Allah SWT controls all events on the surface of the earth. A recent study by Baytiyeh and Öcal (2016) assessed the perceptions of high school students in Turkey and Lebanon revealing that both students in Turkey and Lebanon had a high fatalism attitude towards disaster. $77 \%$ of students in Lebanon and 57 students in Turkey believe that God is likely to give them help when an earthquake strikes (Baytiyeh \& Öcal, 2016).

Religious and cultural factors greatly influence the formation of fatalism beliefs. Most Muslim societies assume that disasters are destiny that Allah has determined where and when they occur. Most Muslim communities in the Middle East believe that Allah SWT controls all events in the future, so that humans cannot do much to avoid / avoid the will of Allah SWT (Baytiyeh \& Naja, 2014). This assumption strengthened when there was a disaster in the 2004 Indian Ocean earthquake and tsunami, most mosques were safe from damage. The same thing happened when the earthquake in Turkey in 2000, where several mosques survived amid the rubble of damaged buildings. This condition makes fatalism beliefs increase. A mosque is a holy place for Muslims, but it is not always safe from damage when a disaster occurs. The 6.5 magnitude earthquake that hit Pidie Jaya District, Aceh Province, Indonesia in 2016 resulted in 196 mosques collapsing and damaged by the earthquake (BNPB, 2019).

Excessive fatalism belief against disasters leads people to ignore knowledge for disaster risk reduction in the future. Yari et al (2019) state that the higher the level of fatalism confidence in disasters made the level of preparedness and actions in disaster management lower. An extreme fatalism attitude causes no positive response when a disaster occurs. The attitude of fatalism that afflicts the community in most Muslim-occupied countries is thought to be caused by misunderstandings in understanding Islamic teachings comprehensively (Chester, Duncan, \& Dhanhani, 2013; Ghafory-Ashtiany, 2009). Islamic teachings can have a positive impact on capacity building in the face of disasters and can make fatalism towards disasters increase if understanding of the Islamic concept is not comprehensively understood.

Basically, Islamic teachings recognize two types of destiny, qada and qadar. Qada is a destiny that God has written before man was born and cannot be changed. Qadar is a destiny that can be changed by trying and praying. Life and death have become the provisions of Allah SWT so that they cannot be changed. However, humans can still try and pray to avoid disasters that can cause death (Ghafory-Ashtiany, 2009).

The story of Noah, as written in the Qur'an, can be a good reference for preparing for disasters (Ghafory-Ashtiany, 2009). The story is explained explicitly in the 23rd surah (Al Mu'minun) verse 27: "Then We revealed to him," Make a ship under our supervision and guidance, so when our orders come and the furnace (kitchen) has emitted water, then put in the ship a pair of each type, also your family, except those who were first set (torment will be overcome) between them. And do not speak with Me about those who do wrong, in fact they will be drowned ".

The lesson that can be taken from Noah is that Allah Almighty ordered Noah to build a ship (ark) to avoid hurricanes and floods that would hit his country. From the order it is clear that there are efforts to reduce disaster risk. Allah SWT encourages people to always try to save themselves. Therefore, to reduce the fatalism attitude of Muslim communities in various parts of the world, the role of religious leaders is very important to convey Islamic teachings that direct the community to prepare themselves and use knowledge in efforts to reduce disaster risk.

\section{Synthesis of Findings}

Figure 2 presents the analysis result of literature related to the role of tacit knowledge (local knowledge) in disaster risk reduction. Basically, local knowledge is obtained through continuous observation and interaction with the environment. It is a cumulative knowledge and transmitted among community members, usually moving from one generation to another. Traditional knowledge is often communicated as oral traditions in the form of historical stories, legends, myths, and songs. Traditional knowledge includes information about ecology, interactions between humans and their environment, and a cosmological understanding of the world (Becker et al., 2008).

Tacit knowledge (know how) in the form of local knowledge is effective in motivating people to take a right action when disaster happens. It has a significant influence on human behavior. There is a lot of evidence that supports tacit knowledge in the form of local knowledge has succeeded in motivating the community to take disaster preparedness action(Lauer, 2012, 2015; McAdoo et al., 2006; Rahman, Sakurai, \& Munadi, 2017; Syahputra, 2018). However, this local knowledge is only owned by certain communities. Therefore, it cannot be used more broadly in the context of disaster risk reduction.

Tacit knowledge is personal, context-specific, often unconscious and therefore hard to formalize and communicate (North \& Kumta, 2014).Therefore, tacit knowledge in the form of local knowledge needs to be converted into explicit knowledge and scientifically validated to produce new knowledge. The new knowledge can be disseminated in order to increase the resilience of the community.

The change of tacit knowledge into explicit knowledge will produce new knowledge. This new knowledge can be disseminated and applied through formal and informal education. One example of excellent evidence for the change of local scientific knowledge to new knowledge is the video of "Run to Higher Ground!". This video has been used as a tsunami disaster mitigation tool in the state of Washington. The video has cross-cultural appeal and has been used as an educational tool for tsunami disaster warning. 


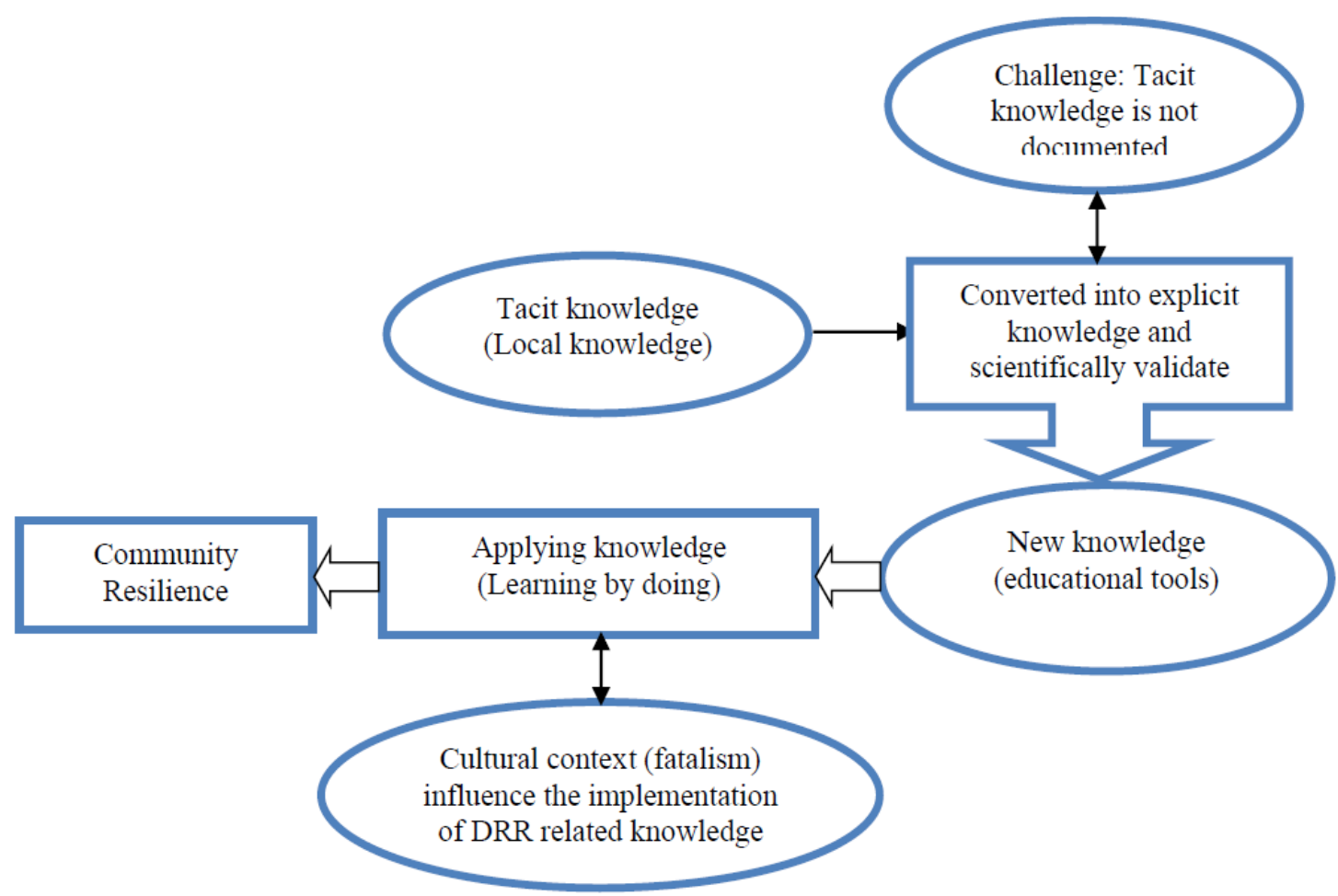

Figure 2. The role of tacit knowledge in increasing community resilience to disasters

In order to motivate people to take preparedness actions, tacit knowledge needs to be applied/ practiced. It is because basically, knowledge has various levels. Firstly "know what" is produced from information. Then "Know what" is transformed into "know how" by way of practice/ application (North \& Kumta, 2014). In the context of disaster risk reduction, turning knowledge into action is a crucial part to increase preparedness(Cadag \& Gaillard, 2012; Gaillard \& Mercer, 2013). Community not only knows about risks, but also knows what to do when a disaster occurs. It is believed to increase resilience to future disasters. Recently, in various parts of the world people know about disasters, but still do not comprehensively understand what to do when disasters occur(Shiwaku \& Shaw, 2008).

Therefore, learning by doing is very important in disaster risk reduction. There is scientific evidence that shows cognitive activities during training (learning by doing) have long-term effects on human neurological function (Eslinger et al., 2009). This training changes the way of thinking, giving reason, and solving problems (Baker, Leon, Greenaway, Collins, \& Movit, 2011). It can motivate people to take disaster preparedness actions and they can take appropriate actions when disasters occur(Hoffmann \& Muttarak, 2017). Smong's knowledge as previously described has been a proof. The message about tsunami disaster and actions that must be taken when a tsunami occurs are delivered continuously to young generation through poetry. The poetry is refreshed at bedtime to the children of Simeulue community and has been embedded in their mind as a tacit knowledge.

However, the process of integrating tacit to explicit knowledge has several challenges, for example there are still a belief in local people that their traditional knowledge is considered sacred and it should not be disseminated to the wider community. Besides, there is a mutual skepticism between local people and policy makers (Giordano, Preziosi,
\& Romano, 2013). There is a belief that only "key" (certain) people in indigenous communities can have this knowledge. Furthermore, traditional knowledge in the form of oral stories is often unwritten, making it very difficult to identify them (Becker et al., 2008). In addition, the process of knowledge integration can also be influenced by differences in perceptions among external experts and a changerelated to the benefits from it (Raymond et al., 2010).

The challenge in reducing a future disaster risk is how to identify and formalize various types of tacit knowledge embedded in the community. If tacit knowledge can be formalized,it can be disseminated and used more broadly. The bottom-upprogram from local community is effective to solve this problem. At present day, many programs of disaster risk reduction to improve disaster preparedness are less effective because they do not consider the social, cultural, and religious conditions of local communities (Adiyoso \& Kanegae, 2017). The programs tend to be top-down. Therefore, they are sometimes not in accordance with the social and cultural conditions of the community.

The result of literature study also found that the application of knowledge often experienced obstacles due to the cultural and social influences of community. It makes the community become fatalistic. The beliefs in fatalism makes people ignore knowledge of disaster risk reduction. Those who hold to the beliefs of fatalism believe in the power of nature or luck (Rashwan \& Jenkins, 2017). Therefore, the fatalism beliefs have to be reduced by involving religious leaders and the media. The role of religious leaders is very important to reduce fatalism beliefs. The religious leaders can play a role in providing a comprehensive understanding of disasters totheir people.

In addition, the media also plays an important role in reducing fatalism beliefs. The way the media presents disaster damage information affects public perception. For example, 
the information conveyed that damage from an earthquake cannot be prevented will increase fatalism beliefs among the people (McClure, Allen, \& Walkey, 2001). Therefore, the media needs to provide educative information such as efforts to prevent damage from earthquakes in order to reduce fatalism beliefs.

\section{Conclusion}

In the context of disaster risk reduction, tacit knowledge embedded in the community in the form of indigenous knowledge plays a major role in increasing capacity when facing disasters. Nevertheless, to be easily understood and disseminated to the wider community, tacit knowledge needs to be formalized. The challenge in disaster risk reduction in the future is how to identify various types of tacit knowledge embedded in the community to be formalized so that they can be disseminated and used more widely. Knowledge built on a bottom up manner that comes from local knowledge is believed to be more effective to be applied.

However, the process of integrating tacit knowledge into explicit knowledge has several challenges. For example, many local people still believe that their traditional knowledge is considered as something sacred so it should not be disseminated to the wider community. Only key people in the indigenous community may possess this knowledge. In addition, indigenous knowledge in the form of oral stories about disasters is often not written so it is very difficult to identify them (Becker et al., 2008).

In addition, the application of knowledge in the efforts of disaster risk reduction is constrained by fatalism beliefs that hit several Islamic countries, especially in the Middle East. This belief is allegedly caused by a misunderstanding in comprehending the teachings of Islam in a comprehensive manner. Confidence in fatalism makes people ignore knowledge in the effort to reduce disaster risk. Serious efforts are needed, especially the role of religious leaders to explain the Islamic perspective in comprehensive disaster risk reduction. Basically, Islamic teachings highly uphold the application of science and technology in various aspects of life.

\section{Acknowledgement}

The author thanks anonymous reviewers who have provided feedback to improve this article.

\section{References}

Adiyoso, W., \& Kanegae, H. (2017). Disaster Risk Reduction in Indonesia. https://doi.org/10.1007/978-3-319-54466-3

Ajith Kumar, J., \& Chakrabarti, A. (2012). Bounded awareness and tacit knowledge: Revisiting Challenger disaster. Journal of Knowledge Management, 16(6), 934-949. https:// doi.org/10.1108/13673271211276209

Akasoy, A. (2007). Islamic attitudes to disasters in the Middle Ages: A comparison of earthquakes and plagues. Medieval History Journal, 10(1-2), 387-410. https:// doi.org/10.1177/097194580701000214

Alshehri, S. A., Rezgui, Y., \& Li, H. (2013). Public perception of the risk of disasters in a developing economy: The case of Saudi Arabia. Natural Hazards, 65(3), 1813-1830. https:// doi.org/10.1007/s11069-012-0445-5

Baker, D. P., Leon, J., Greenaway, E. G. S., Collins, J., \& Movit, M. (2011). The Education Effect on Population Health: A Reassessment. Population and Development Review, 37(2), 307-332.
Baytiyeh, H., \& Naja, M. K. (2014). Can education reduce middle eastern fatalistic attitude regarding earthquake disasters? Disaster Prevention and Management, 23(4), 343-355. https://doi.org/10.1108/DPM-12-2013-0219

Baytiyeh, H., \& Öcal, A. (2016). High school students' perceptions of earthquake disaster: A comparative study of Lebanon and Turkey. International Journal of Disaster Risk Reduction, 18, 56-63. https://doi.org/10.1016/j.ijdrr.2016.06.004

Becker, J., Johnston, D., Lazrus, H., Crawford, G., \& Nelson, D. (2008). Use of traditional knowledge in emergency management for tsunami hazard: A case study from Washington State, USA. Disaster Prevention and Management: An International Journal, 17(4), 488-502. https://doi.org/10.1108/09653560810901737

BNPB. (2019). Data Informasi Bencana Indonesia. Retrieved from Badan Nasional Penanggulangan Bencana website: https:// bnpb.cloud/dibi/

Boiral, O. (2002). Tacit knowledge and environmental management. Long Range Planning, 35(3), 291-317. https:// doi.org/10.1016/S0024-6301(02)00047-X

Bosschaart, A., Kuiper, W., van der Schee, J., \& Schoonenboom, J. (2013). The role of knowledge in students' flood-risk perception. Natural Hazards, 69(3), 1661-1680. https:// doi.org/10.1007/s11069-013-0774-z

Cadag, J. R. D., \& Gaillard, J. C. (2012). Integrating knowledge and actions in disaster risk reduction: The contribution of participatory mapping. Area, 44(1), 100-109. https:// doi.org/10.1111/j.1475-4762.2011.01065.x

Chester, D. K., Duncan, A. M., \& Dhanhani, H. A. G. (2013). Volcanic eruptions, earthquakes and Islam. Disaster Prevention and Management: An International Journal, 22 (3), 278-292. https://doi.org/10.1108/DPM-04-2013-0079

Dalkir, K. (2013). Knowledge Management in Theory and Practice. https://doi.org/10.1002/asi.21613

Eslinger, P. J., Blair, C., Wang, J. L., Lipovsky, B., Realmuto, J., Baker, D., ... Yang, Q. X. (2009). Developmental shifts in fMRI activations during visuospatial relational reasoning. Brain and Cognition, 69(1), 1-10. https://doi.org/10.1016/ j.bandc.2008.04.010

Fazey, I., Proust, K., Newell, B., Johnson, B., \& Fazey, J. A. (2006). Eliciting the implicit knowledge and perceptions of onground conservation managers of the Macquarie Marshes. Ecology and Society, 11(1). https://doi.org/10.5751/ES-01665 $-110125$

Gaillard, J. C., \& Mercer, J. (2013). From knowledge to action: Bridging gaps in disaster risk reduction. Progress in Human Geography, 37(1), 93-114. https:// doi.org/10.1177/0309132512446717

Gao, F., Meng, M., \& Clarke, S. (2008). Knowledge, management, and knowledge management in business operations. Journal of Knowledge Management, 12(2), 3-17. https:// doi.org/10.1108/13673270810859479

Ghafory-Ashtiany, M. (2009). View of Islam on earthquakes, human vitality and disaster. Disaster Prevention and Management: An International Journal, 18(3), 218-232. https:// doi.org/10.1108/09653560910965600

Giordano, R., Preziosi, E., \& Romano, E. (2013). Integration of local and scientific knowledge to support drought impact monitoring: Some hints from an Italian case study. Natural Hazards, 69(1), 523-544. https://doi.org/10.1007/s11069-013 -0724-9

Hiwasaki, L., Luna, E., Syamsidik, \& Shaw, R. (2014). Process for integrating local and indigenous knowledge with science for hydro-meteorological disaster risk reduction and climate change adaptation in coastal and small island communities. International Journal of Disaster Risk Reduction, 10, 15-27. https://doi.org/10.1016/j.ijdrr.2014.07.007

Hoffmann, R., \& Muttarak, R. (2017). Learn from the Past, Prepare for the Future: Impacts of Education and Experience on Disaster Preparedness in the Philippines and Thailand. World Development, 96, 32-51. https://doi.org/10.1016/ 
j.worlddev.2017.02.016

Iemura, H., Takahashi, Y., Pradono, M. H., Sukamdo, P., \& Kurniawan, R. (2006). Earthquake and tsunami questionnaires in Banda Aceh and surrounding areas. Disaster Prevention and Management: An International Journal, 15(1), 21-30. https:// doi.org/10.1108/09653560610654211

Kaklauskas, A., Amaratunga, D., \& Haigh, R. (2009). Knowledge Model for Post-Disaster Management. International Journal of Strategic Property Management, 13(2), 117-128. https:// doi.org/10.3846/1648-715x.2009.13.117-128

Kanhai, L. D. K., Singh, D., Lauckner, B., Ebi, K. L., \& Chadee, D. D. (2016). Knowledge, attitude and practices of coastal communities in Trinidad and Tobago about tsunamis. Natural Hazards, 81(2), 1349-1372. https://doi.org/10.1007/ s11069-015-2138-3

Lauer, M. (2012). Oral traditions or situated practices? Understanding how indigenous communities respond to environmental disasters. Human Organization, 71(2), 176187. https://doi.org/10.17730/humo.71.2.j0w0101277ww6084

Lauer, M. (2015). Oral Traditions or Situated Practices? Understanding How Indigenous Communities Respond to Environmental Disasters. Human Organization, 71(2), 176187. https://doi.org/10.17730/humo.71.2.j0w0101277ww6084

Mardiatno, D., Malawani, M. N., Annisa, D. N., \& Wacano, D. (2017). Review on tsunami risk reduction in Indonesia based on coastal and settlement typology. Indonesian Journal of Geography, 49(2), 186-194. https://doi.org/10.22146/ ijg.28406

McAdoo, B. G., Dengler, L., Prasetya, G., \& Titov, V. (2006). Smong: How an oral history saved thousands on Indonesia's Simeulue Island during the December 2004 and March 2005 tsunamis. Earthquake Spectra, 22(SUPPL. 3). https:// doi.org/10.1193/1.2204966

McAdoo, B. G., Moore, A., \& Baumwoll, J. (2009). Indigenous knowledge and the near field population response during the 2007 Solomon Islands tsunami. Natural Hazards, 48(1), 7382. https://doi.org/10.1007/s11069-008-9249-z

McClure, J., Allen, M. W., \& Walkey, F. (2001). Countering fatalism: Causal information in news reports affects judgments about earthquake damage. Basic and Applied Social Psychology, 23 (2), 109-121. https://doi.org/10.1207/ S15324834BASP2302_3

Mercer, J., Kelman, I., \& Dekens, J. (2009). Integrating indigenous and scientific knowledge for disaster risk reduction. Indigenous Knowledge and Disaster Risk Reduction: From Practice to Policy, 34(1), 214-239.

Mercer, Jessica, Dominey-Howes, D., Kelman, I., \& Lloyd, K. (2007). The potential for combining indigenous and western knowledge in reducing vulnerability to environmental hazards in small island developing states. Environmental Hazards, 7(4), 245-256. https://doi.org/10.1016/ j.envhaz.2006.11.001

Murumba, J. W. (2020). Tacit knowledge management at universities in Kenya. 8(July). https://doi.org/10.36965/ OJAKM.2020.8)

Nakanishi, H., \& Black, J. (2018). Implicit and explicit knowledge in flood evacuations with a case study of Takamatsu, Japan. International Journal of Disaster Risk Reduction, 28 (December 2017), 788-797. https://doi.org/10.1016/ j.ijdrr.2018.02.008

Nonaka, I., \& Takeuchi. (1995). The knowledge creating company. Oxford University Press.

North, K., \& Kumta, G. (2014). Knowledge management. https:// doi.org/10.1192/apt.8.5.387

Paradise, T. R. (2005). Perception of earthquake risk in Agadir, Morocco: A case study from a Muslim community. Environmental Hazards, 6(3), 167-180. https:// doi.org/10.1016/j.hazards.2006.06.002

Pathirage, C., Seneviratne, K., Amaratunga, D., \& Haigh, R. (2012).
Managing disaster knowledge: Identification of knowledge factors and challenges. International Journal of Disaster Resilience in the Built Environment, 3(3), 237-252. https:// doi.org/10.1108/17595901211263620

Rahman, A., Sakurai, A., \& Munadi, K. (2017). Indigenous knowledge management to enhance community resilience to tsunami risk: lessons learned from Smong traditions in Simeulue island, Indonesia. IOP Conf. Series: Earth and Environmental Science, 56. https://doi.org/10.1088/17551315/56/1/012018

Rahman, A., Sakurai, A., \& Munadi, K. (2018). The analysis of the development of the Smong story on the 1907 and 2004 Indian Ocean tsunamis in strengthening the Simeulue island community's resilience. International Journal of Disaster Risk Reduction, 29, 13-23. https://doi.org/10.1016/ j.ijdrr.2017.07.015

Rashwan, B., \& Jenkins, J. C. (2017). Fatalism and revolution: expanding our understanding of fatalism during a unique political opening in Egypt. Journal of North African Studies, 22(4), 645-664

https:// doi.org/10.1080/13629387.2017.1316716

Raymond, C. M., Fazey, I., Reed, M. S., Stringer, L. C., Robinson, G. M., \& Evely, A. C. (2010). Integrating local and scientific knowledge for environmental management. Journal of Environmental Management, 91(8), 1766-1777. https:// doi.org/10.1016/j.jenvman.2010.03.023

Sakurai, A., Bisri, M. B. F., Oda, T., Oktari, R. S., Murayama, Y., Nizammudin, \& Affan, M. (2018). Exploring minimum essentials for sustainable school disaster preparedness: A case of elementary schools in Banda Aceh City, Indonesia. International Journal of Disaster Risk Reduction, 29, 73-83. https://doi.org/10.1016/j.ijdrr.2017.08.005

Seneviratne, K., Baldry, D., \& Pathirage, C. (2010). Disaster Knowledge Factors in Managing Disasters Successfully. International Journal of Strategic Property Management, 14 (4), 376-390. https://doi.org/10.3846/ijspm.2010.28

Setten, G., \& Lein, H. (2019). "We draw on what we know anyway": The meaning and role of local knowledge in natural hazard management. International Journal of Disaster Risk Reduction, 38. https://doi.org/10.1016/j.ijdrr.2019.101184

Shiwaku, K., \& Shaw, R. (2008). Proactive co-learning: A new paradigm in disaster education. Disaster Prevention and Management: An International Journal, 17(2), 183-198. https://doi.org/10.1108/09653560810872497

Songlar, T., Pussadee La-or, N. P., Chomchoe, C., \& Khunthason, S. (2019). Knowledge, attitude and practice (KAP) of earthquake preparedness amongst the elderly in risk areas: Chiang Rai, Thailand. Journal of Health Research, 33(1), 213. https://doi.org/10.1108/JHR-12-2018-0167

Spiekermann, R., Kienberger, S., Norton, J., Briones, F., \& Weichselgartner, J. (2015). The Disaster-Knowledge Matrix Reframing and evaluating the knowledge challenges in disaster risk reduction. International Journal of Disaster Risk Reduction, 13, 96-108. https://doi.org/10.1016/ j.ijdrr.2015.05.002

Syahputra, H. (2018). Indigenous knowledge representation in mitigation process: a study of communities' understandings of natural disasters in Aceh Province, Indonesia. Collection and Curation. https://doi.org/10.1108/cc-11-2017-0046

UNISDR. (2015). Sendai Framework for Disaster Risk Reduction $2015-20301$.

Wachinger, G., Renn, O., Begg, C., \& Kuhlicke, C. (2013). The risk perception paradox-implications for governance and communication of natural hazards. Risk Analysis, 33(6), 1049-1065. 6924.2012.01942.x

Walshe, R. A., \& Nunn, P. D. (2012). Integration of indigenous knowledge and disaster risk reduction: A case study from Baie Martelli, Pentecost Island, Vanuatu. International Journal of Disaster Risk Science, 3(4), 185-194. https:// 
doi.org/10.1007/s13753-012-0019-x

Weichselgartner, J., \& Pigeon, P. (2015). The Role of Knowledge in Disaster Risk Reduction. International Journal of Disaster Risk Science, 6(2), 107-116. https://doi.org/10.1007/s13753015-0052-7

Yari, A., Zarezadeh, Y., \& Ostadtaghizadeh, A. (2019). Prevalence of Fatalistic Attitudes toward Earthquake Disaster Risk Management in Citizens of Tehran, Iran. International Journal of Disaster Risk Reduction, 38. https:// doi.org/10.1016/j.ijdrr.2019.101181

Zhang, D., Zhou, L., \& Nunamaker Jr, J. F. (2002). A Knowledge Management Framework for the Support of Decision Making in Humanitarian Assistance/Disaster Relief. Knowledge and Information Systems, 4(3), 370-385. https:// doi.org/10.1007/s101150200012 